\title{
Effects of Chloride and Ammonium Salts on the Incidence of Phytophthora Root and Stem Rot of Soybean
}

\author{
C. H. Canaday and A. F. Schmitthenner, Department of Plant Pathology, The Ohio State University, Ohio Agricul- \\ tural Research and Development Center, Wooster 44691
}

\begin{abstract}
Canaday, C. H., and Schmitthenner, A. F. 2010. Effects of chloride and ammonium salts on the incidence of Phytophthora root and stem rot of soybean. Plant Dis. 94:758-765.

In growth chamber experiments using field soil naturally infested with Phytophthora sojae, addition of $\mathrm{KCl}$ at 150 to $400 \mu \mathrm{g}$ of $\mathrm{K}$ per gram of dry soil increased the incidence of Phytophthora root and stem rot on susceptible soybean (Glycine max) compared with a distilled water control. Other potassium salts at 150 to $400 \mu \mathrm{g}$ of K, phosphorus salts at 20 to $317 \mu \mathrm{g}$ of $\mathrm{P}$, and sulfate salts of $\mathrm{K}, \mathrm{Ca}, \mathrm{Mg}, \mathrm{Na}$, and $\mathrm{Al}$ at $491 \mu \mathrm{g}$ of $\mathrm{SO}_{4}$ per gram of soil did not affect disease incidence. Application of chloride salts of $\mathrm{K}, \mathrm{Na}, \mathrm{Mg}, \mathrm{Ca}, \mathrm{NH}_{4}, \mathrm{Al}, \mathrm{Fe}$, and $\mathrm{Sr}$ at $250 \mu \mathrm{g}$ of $\mathrm{Cl}$ per gram of soil all increased disease incidence compared with the distilled water control. Addition of other ammonium salts also increased disease incidence. Disease incidence increased when $\mathrm{KCl}$ at $300 \mu \mathrm{g}$ of $\mathrm{K}$ per gram soil was applied to naturally infested Blount silt loam but not to naturally infested Hoytville silty clay. The effects of chloride salts on plant growth and on natural inoculum of $P$. sojae were investigated. At $450 \mu \mathrm{g} \mathrm{Cl} / \mathrm{g}$ of soil, addition of $\mathrm{NaCl}$ increased plant fresh weight but had no effect on germination, emergence, transpiration, height, and dry weight of plants grown in pasteurized, pathogen-free soil. When soybean plants were grown without a deplasmolytic shock and without promoting zoospore release by saturating the soil, the addition of chloride salts at $304 \mu \mathrm{g}$ of $\mathrm{Cl}$ per gram of soil increased disease. In a leafdisc-baiting bioassay, leaf infection by $P$. sojae zoospores decreased when 0.01 or $0.02 \mathrm{M} \mathrm{KCl}$ was added to soil extracts from flooded soil but was unaffected by $\mathrm{KCl}$ at 150 to $600 \mu \mathrm{g}$ of $\mathrm{K}$ per gram of soil applied to the soil 5 days before baiting. Energy-dispersive X-ray analysis of taproots of 5-day-old soybean plants indicated a reduction in the calcium content of the outer cell layers with $\mathrm{KCl}$ at $400 \mu \mathrm{g}$ of $\mathrm{K}$ per gram of soil but not with $\mathrm{K}_{2} \mathrm{SO}_{4}$. Disease increases with addition of $\mathrm{KCl}$ appear to be due to the presence of chloride and may be associated with changes in the micropartitioning of root calcium.
\end{abstract}

Phytophthora root and stem rot is one of the most important diseases of soybean Glycine max (L.) Merr. in Ohio. The causal pathogen, Phytophthora sojae Kaufm. \& Gerd., attacks soybean at all stages of growth, causing pre- and post-emergence damping-off, root and stem rot, stunting, wilting, and death of older plants $(22,39)$. It is particularly a problem in northwest Ohio, where many of the soils are lacustrine, fine textured, and poorly drained. Soil saturation, a common occurrence after

Corresponding author: C. H. Canaday

E-mail: ccanaday@utk.edu

Current address of C. H. Canaday: Department of Entomology and Plant Pathology, The University of Tennessee, West Tennessee Research and Education Center, Jackson 38301.

Portion of Ph.D. dissertation of C. H. Canaday.

Mention of trade names or commercial products in this publication is solely for the purpose of providing specific information and does not imply recommendation or endorsement by The Ohio State University.

Accepted for publication 4 March 2010

doi:10.1094/PDIS-94-6-0758

(C) 2010 The American Phytopathological Society heavy rains, promotes zoospore release (28) and subsequent disease. An integrated control program combining improved surface and subsurface drainage with resistant or tolerant sensu Mussell (29) soybean cultivars plus a fungicide seed treatment are currently used to minimize losses to this disease $(16,34,36,37)$.One component of an integrated disease control program that needed study was the effect of fertilization of Ohio soils on disease. Soybean plants require substantial amounts of potassium and phosphorous fertilization for maximum yield. Some soils, especially high clay soils in Ohio, require higher potassium levels to support optimum crop growth (46). Fertilizers can increase, decrease, or have no effect on diseases caused by Phytophthora spp. (35). Nitrogen fertilization has been reported to increase Phytophthora root and stem rot of soybean (11). Ammonium ions were implicated in the observed disease enhancement. Dirks et al. (15) observed increased disease severity using a complete fertilizer and suggested that the increase was due to the nitrogen component. Pacumbaba et al. (30) reported that muriate of potash increased the incidence of Phytophthora rot of soybean in a northern Alabama soil whereas a complete fertilizer reduced dis- ease. Potassium chloride has been associated with increases in the incidence of other seedling diseases of soybean and snap bean (8-10). The following experiments were initiated to evaluate the potential effects of potassium and phosphorus fertilizer salts on Phytophthora root and stem rot of soybean using Ohio soils naturally infested with $P$. sojae. Other salts were included in subsequent studies to ascertain the probable reason for effects observed with potassium chloride. A preliminary report has been published (14).

\section{MATERIALS AND METHODS}

Soils and their analyses. Soil naturally infested with $P$. sojae was used in all experiments. Over $1,400 \mathrm{~kg}$ of moist Fulton silty clay (fine, illitic, mesic Aeric Ochraqualf) collected from the North Central Branch of the Ohio Agricultural Research and Development Center (OARDC) near Vickery, $\mathrm{OH}$, was used for most experiments. Small quantities $(90 \mathrm{~kg}$ of moist soil) of a naturally infested Hoytville silty clay (fine, illitic, mesic, Mollic Ochraqualf) from the Northwestern Branch of OARDC near Hoytville, $\mathrm{OH}$, and of a naturally infested Blount silt loam (fine, illitic, mesic, Aeric Ochraqualf) from a farm near Van Wert, $\mathrm{OH}$, were collected and used to compare results obtained with the Fulton silty clay. The three soils were representative of those typically found in northern and northwest Ohio, where Phytophthora root and stem root is particularly a problem.

Soils were stored at the moisture content at which they were collected (19.1 to $28.6 \% \mathrm{H}_{2} \mathrm{O}$ by weight) in sealed polyethylene bags at $5^{\circ} \mathrm{C}$ for 4 to 14 months before use. Representative subsamples were used to develop wetting and drying moisture-characteristic curves using Buchner funnel tensiometers and ceramic pressure plates $(21,33)$. The curves were used to estimate soil water matric potential $\left(\psi_{\mathrm{m}}\right)$ in experiments based on the average soil moisture content of the soil in experimental units. Two representative subsamples of each soil were sent to the ResearchExtension Analytical Laboratory, OARDC, Wooster, for analysis of soil $\mathrm{pH}$; cation exchange capacity; available $\mathrm{P}$; and exchangeable $\mathrm{K}, \mathrm{Ca}$, and $\mathrm{Mg}$ by standard methods. Samples were also sent to G. Taylor and M. Ransom, Department of Agronomy, The Ohio State University, for soil particle analysis by standard methods. 
A modified quantitative bioassay that uses leaf-disc baits (13) was used to determine the best soil incubation temperature to maximize zoospore release. Two samples of the Fulton silty clay were packed into 600 -ml beakers at a bulk density of $1.15 \mathrm{~g} / \mathrm{cm}^{3}$. Sufficient glass-distilled water (DW) was then added to each beaker to bring the soil moisture up to a $\psi_{\mathrm{m}}$ of -20 to $-45 \mathrm{kPa}$ before placing the beakers in polyethylene bags. Bagged beakers were incubated in the dark at $15,20,25$, or $30^{\circ} \mathrm{C}$. Five $10-\mathrm{g}$ subsamples of moist soil were removed every fourth day from each beaker, placed in 50-ml beakers, flooded with $20 \mathrm{ml}$ of DW at $20^{\circ} \mathrm{C}$, and baited with 21 leaf-disc baits freshly punched with a handheld paper punch from the unifoliolate leaves of 12- to 14-day-old Amsoy soybean. Debris was removed from the water surface with a piece of tissue paper before adding the leaf discs. Baits were placed with the upper leaf surface in contact with the water, removed after $2.5 \mathrm{~h}$, and plated on clarified V8 juice agar supplemented with yeast extract, sucrose, cholesterol, pentachloronitrobenzene, benomyl, neomycin sulfate, rifampicin, and hymexazol (VYS/PBNRH) (12). The forceps used to transfer the baits to the selective medium were flamed and cooled between each leaf disc.

General design and experimental units. Cardboard milk cartons (1.9-liter) were used as potting containers in growthchamber experiments and were the experimental units for treatment applications. Tops were cut off to create 9.7-by-9.7-by$13-\mathrm{cm}$ containers without drainage holes. Collected Fulton silty clay was removed from $5^{\circ} \mathrm{C}$ storage, passed through a $1.2-\mathrm{cm}$ mesh screen, and thoroughly mixed. Aliquots of soil (595 g dry wt) were packed into cartons at a bulk density of $1.15 \mathrm{~g} / \mathrm{cm}^{3}$ to a depth of $5.5 \mathrm{~cm}$. Sufficient DW was then added to each carton to bring the soil moisture up to a $\psi_{\mathrm{m}}$ of -20 to $-45 \mathrm{kPa}$ before placing the cartons in sealed polyethylene bags. Bagged cartons were incubated in the dark at 22 to $25^{\circ} \mathrm{C}$ for 9 to 20 days before removing them, planting soybean seed, and adding treatments.

Randomized complete block designs were used in all tests. To increase the sensitivity of detection of treatment effects, the susceptible soybean cv. Sloan with little tolerance or partial resistance to Phytophthora root and stem rot was used for all experiments (17). Twelve seeds treated with captan (Orthocide 75; Chevron Chemical Co., Ortho Division, San Francisco) at $0.8 \mathrm{~g}$ a.i. $/ \mathrm{kg}$ of seed were placed on the surface of the soil in each carton. Seed were covered with an aliquot of soil $(150 \mathrm{~g})$ and the topsoil packed by dropping a 9-by-9-by-32-cm board (1.1 kg) onto the soil from a height of $5 \mathrm{~cm}$. Test salts were then added in $25 \mathrm{ml}$ of DW to the surface of the topsoil. Controls in all experiments received DW only. Analytical-grade re- agents were used in all experiments except when urea was used. The latter was applied as a commercial fertilizer (45-0-0) in two of the tests. Sufficient additional DW was then added to each carton to bring the soil moisture up to a $\psi_{\mathrm{m}}$ of $-3 \mathrm{kPa}$. Cartons were then sealed in polyethylene bags to prevent drying of the soil and placed in a 24 to $25^{\circ} \mathrm{C}$ growth chamber with a $14-\mathrm{h}$ photoperiod of $340 \mu \mathrm{E} / \mathrm{m}^{2} \mathrm{~s}^{-1}$ from fluorescent + incandescent lighting.

Four days after planting, cartons were removed from the bags. The soil was then saturated with DW to $0.5 \mathrm{~cm}$ above the surface of the soil to permit zoospore release (28). Once evapotranspiration had removed excess free water, cartons were watered regularly by weight to equalize the soil moisture of all cartons. Seed germination was recorded as the percentage of seed observed to emerge or partially emerge during an experiment. Soil moisture was gradually reduced by watering cartons to a lower weight each day until a $\psi_{\mathrm{m}}$ of approximately $-700 \mathrm{kPa}$ was reached. Cartons were then watered daily to a soil moisture of approximately $-5 \mathrm{kPa}$ $\psi_{\mathrm{m}}$ until the end of experiments 15 to 22 days after planting, when further postemergence damping-off appeared to be ceasing. Diseased seedlings were collected during experiments, surface disinfected in $1 \%$ sodium hypochlorite for 10 to $30 \mathrm{~s}$, and plated on VYS/PBNRH medium. At the end of experiments, the mean height from soil surface to growing point of the remaining plants was recorded to the nearest whole centimeter. Plant hypocotyls were then split and examined for internal necrosis. Disease incidence was recorded as ([plants killed + plants with internal hypocotyl necrosis]/seed germination) $x$ $100 \%$. Arcsine-transformed percentages were used in analysis of variance using PC SAS (version 9.1; SAS Institute, Cary, NC). Original percentages are used in tables but letters following means are based on mean separation tests of arcsinetransformed data.

Effects of $\mathrm{K}, \mathrm{P}, \mathrm{SO}_{4}, \mathrm{Cl}$, and $\mathrm{NH}_{4}$ salts on disease incidence and plant height. Using the above procedures, a series of growth chamber experiments was conducted to evaluate the effects of potassium, phosphorus, sulfate, chloride, and ammonium salts on the incidence of Phytophthora root and stem rot and on plant height. Treatments were replicated six times in the first four tests. All these tests included the DW control. The initial test included $\mathrm{KCl}$ and $\mathrm{K}_{2} \mathrm{SO}_{4}$ at 150 and 200 $\mu \mathrm{g}$ of $\mathrm{K}, \mathrm{KNO}_{2}$ at $100 \mu \mathrm{g}$ of $\mathrm{K}, \mathrm{KNO}_{3}$ at $200 \mu \mathrm{g}$ of $\mathrm{K}, \mathrm{Ca}\left(\mathrm{H}_{2} \mathrm{PO}_{4}\right)_{2}$ at 20 and $40 \mu \mathrm{g}$ of $\mathrm{P}$, and $\mathrm{K}_{2} \mathrm{HPO}_{4}$ at $40 \mu \mathrm{g}$ of $\mathrm{P}$ per gram of soil. Disease incidence and plant heights were recorded after 15 days.

In a second test, higher rates of potassium, chloride, and sulfate salts included $\mathrm{KCl}, \quad \mathrm{K}_{2} \mathrm{SO}_{4}, \quad \mathrm{KH}_{2} \mathrm{PO}_{4}, \quad \mathrm{~K}_{2} \mathrm{HPO}_{4}$, and $\mathrm{KHCO}_{3}$ at $400 \mu \mathrm{g}$ of $\mathrm{K}$ per gram of soil.
The $\mathrm{KCl}$ was applied both with and without metalaxyl. Metalaxyl (Ridomil 2E; Ciba-Geigy Ltd. Greensboro, NC) was applied at $5 \mu \mathrm{g}$ a.i./g of soil in the $\mathrm{KCl}$ treatment solution to confirm that disease losses were due solely to fungal pathogens in the order Peronosporales (38). Chloride salts of $\mathrm{Na}$ and $\mathrm{Mg}$ at $363 \mu \mathrm{g}$ of $\mathrm{Cl} ; \mathrm{CaSO}_{4}$ at 491 and $982 \mu \mathrm{g}$ of $\mathrm{SO}_{4}$; and sulfate salts of $\mathrm{Na}, \mathrm{Mg}$, and $\mathrm{Al}$ at $491 \mu \mathrm{g}$ of $\mathrm{SO}_{4}$ per gram of soil were included in the test to examine further the effects of $\mathrm{SO}_{4}$ and $\mathrm{Cl}$ salts on disease incidence and plant height. Disease incidence and plants heights were recorded after 18 days.

The third test looked at the effects of six potassium salts with $\mathrm{K}$ at $300 \mu \mathrm{g} / \mathrm{g}$ of soil: $\mathrm{KCl}, \mathrm{K}_{2} \mathrm{SO}_{4}, \mathrm{KNO}_{3}, \mathrm{~K}_{2} \mathrm{HPO}_{4}, \mathrm{KH}_{2} \mathrm{PO}_{4}$, and $\mathrm{KHCO}_{3}$. A fourth test looked at the effects of nine chloride salts with $\mathrm{Cl}$ at 250 $\mu \mathrm{g} / \mathrm{g}$ of soil: $\mathrm{KCl}, \mathrm{NaCl}, \mathrm{MgCl}_{2}, \mathrm{CaCl}_{2}$, $\mathrm{NH}_{4}, \mathrm{AlCl}_{3}, \mathrm{FeCl}_{2}, \mathrm{FeCl}_{3}$, and $\mathrm{SrCl}_{2}$. Disease incidence and plant heights were recorded after 22 days. The electrical conductivity of the soil solution in cartons was determined after the end of the third and fourth experiments on three randomly selected replicates or treatment by resaturating the soil cartons with DW, pouring off the excess free water after $24 \mathrm{~h}$, and measuring the conductivities of the clear, filtered extracts using a solu bridge (model SD-B15; Beckman Instruments Inc., Cedar Grove, NJ).

Additional tests were conducted to further verify the nature of disease incidence increases that had been observed with chloride and ammonium salts. $\mathrm{NH}_{4} \mathrm{NO}_{3}$, $\mathrm{NaCl}, \mathrm{NaNO}_{3}, \mathrm{NH}_{4} \mathrm{Cl}$, and urea with $\mathrm{Cl}$ at $304 \mu \mathrm{g} / \mathrm{g}$ of soil or $\mathrm{N}$ at $120 \mu \mathrm{g} / \mathrm{g}$ of soil were evaluated for 20 days for their effects on disease incidence and plant height. Urea was evaluated both with and without a pyroxyfur seed treatment (Grandstand; Dow Chemical Co., Midland, MI). The pyroxyfur was included to determine whether or not the seed treatment could minimize disease losses to $P$. sojae (36). Treatments were replicated eight times. The same salts were tested in another experiment in which pyroxyfur seed treatment was not included. In this test, disease incidence was assessed in the absence of moisture stress or a deplasmolytic shock by never saturating the soil to induce zoospore release. After planting and adding sufficient additional water to bring the soil moisture up to a $\psi_{\mathrm{m}}$ of $-5 \mathrm{kPa}$, each soil carton was sealed in its own polyethylene bag and returned to the growth chamber. The soybean plants were grown for 11 days in the bags and disease incidence then recorded. Treatments were replicated eight times.

The effects of $\mathrm{KCl}, \mathrm{K}_{2} \mathrm{SO}_{4}, \mathrm{CO}\left(\mathrm{NH}_{2}\right)_{2}$, $\left(\mathrm{NH}_{4}\right)_{2} \mathrm{SO}_{4}, \mathrm{NH}_{4} \mathrm{Cl}, \mathrm{Ca}\left(\mathrm{NO}_{3}\right)_{2}, \mathrm{NaNO}_{3}$, and $\mathrm{KCl}+\mathrm{Ca}\left(\mathrm{NO}_{3}\right)_{2}$ at $300 \mu \mathrm{g}$ of $\mathrm{K}, 272$ $\mu \mathrm{g}$ of $\mathrm{Cl}$, or $108 \mu \mathrm{g}$ of $\mathrm{N}$ per gram of soil also were evaluated in the Hoytville silty clay and the Blount silt loam. Disease 
incidence and plant heights were recorded after 18 days. Treatments were replicated six times.

Finally, the effect of a chloride salt on plant growth in the absence of disease was assessed by growing Sloan soybean in cartons of pasteurized Fulton silty clay with and without $\mathrm{NaCl}$ with $\mathrm{Cl}$ at $450 \mu \mathrm{g} / \mathrm{g}$ of soil. Soil was pasteurized prior to planting by heating the soil cartons in sealed polyethylene bags in a water bath for $10 \mathrm{~h}$ at 50 to $55^{\circ} \mathrm{C}$. This eliminated any detectable inoculum of $P$. sojae using the leafdisc bioassay (13). Treatments were replicated six times. Seedling emergence was recorded as the number of seedlings 4 days after planting with cotyledons above the soil surface and germination as the number of seedlings visible 9 days after planting. Evapotranspiration was determined by the change in weight of the cartons over a $37-\mathrm{h}$ period 20 to 21 days after planting. Plants were excised below the cotylendonary node on the 21 st day, weighed, and dried for $48 \mathrm{~h}$ at $45^{\circ} \mathrm{C}$.

Effects of $\mathrm{K}$ salts on nutrient levels in soybean seedlings. The effect of potassium salts on nutrient levels in soybean root tissues was determined with energydispersive X-ray (EDX) analysis. Sloan soybean plants were grown in cartons of pasteurized Fulton silty clay with $\mathrm{KCl}$ or $\mathrm{K}_{2} \mathrm{SO}_{4}$ at $400 \mu \mathrm{g}$ of $\mathrm{K}$ per gram of soil. The control had only DW. Plants were grown for 5 days without soil saturation, then collected for EDX analysis. A portion of the taproot of each collected seedling was wiped clean of adhering soil with cotton swabs dampened with DW. Segments, $1 \mathrm{~cm}$ long, were cut from these portions and immediately oven dried at $45^{\circ} \mathrm{C}$. Intact taproot segments were mounted horizontally on carbon plachettes with silver paint for EDX analysis. Analyses were conducted using an International Scientific Instruments scanning electron microscope, model ISI-40, interfaced with an EDX 9100 X-ray analyzer. The scanning electron microscope was operated at an accelerating voltage of $30 \mathrm{kV}$ with a 23 $\mathrm{mm}$ working distance and $45^{\circ}$ tilt. Elemental analyses at a magnification of $\times 500$ were conducted at a counting rate of 3,050 \pm 150 counts/s until total counts exceeded three times full scale. Analyses of $\mathrm{Mg}, \mathrm{P}$, $\mathrm{S}, \mathrm{Cl}, \mathrm{K}$, and $\mathrm{Ca}$ were made along lines perpendicular or oblique to the axis of the specimens. Treatments were replicated four times and four analyses were made per replication. EDX analysis was also used to analyze leaf discs $(0.5 \mathrm{~cm}$ in diameter) punched from unifoliolate leaves of 17-day-old Sloan soybean grown in naturally infested soil with and without $\mathrm{KCl}$ at $300 \mu \mathrm{g}$ of $\mathrm{Cl}$ per gram of soil.

Sloan soybean plants were also grown in cartons of pasteurized Fulton silty clay for 10 days with $\mathrm{KCl}$ or $\mathrm{K}_{2} \mathrm{SO}_{4}$ at $400 \mu \mathrm{g}$ of $\mathrm{K}$ per gram of soil or with only DW. The soil in all treatments was saturated with DW 5 days after planting. Stems and leaves of eight plants from each of these cartons were collected 10 days after planting for conventional mineral analyses. Collected stems and leaves were oven dried at $45^{\circ} \mathrm{C}$, then ground in a Wiley mill with a 30 mesh screen. Ground samples were digested in perchloric or nitric acid and analyzed for $\mathrm{Ca}$ and $\mathrm{Mg}$ using a Varian model AA-475 Atomic Absorption Spectrophotometer. Potassium was determined by atomic emission spectrophotometry. Sulfur was determined using turbidimetric techniques (6). Phosphorus was determined by a modified Murphy-Riley method (23). Treatments were replicated four times.

Effect of $\mathrm{KCl}$ on inoculum of $P$. sojae. A quantitative leaf-disc baiting bioassay (13) was used to assess the effects of $\mathrm{KCl}$ on natural inoculum of $P$. sojae in soil. A soil slurry was prepared by mixing naturally infested Fulton silty clay with cold $\left(5^{\circ} \mathrm{C}\right) \mathrm{DW}(1: 1)$ in a Waring blender for 1 min. Aliquots of slurry $(80 \mathrm{~g})$ were poured into cylinders (PVC pipe couplings, 6.0$\mathrm{cm}$ inner diameter) with bottom ends covered with a single layer of cheesecloth secured with a rubber band to retain the slurry. Cylinders were placed on stacks of paper towels in a $5^{\circ} \mathrm{C}$ cooler to prevent oospore germination while excess water was absorbed from the slurry. After approximately 5 days, the slurry had dried to a "soil cake" with a $\psi_{\mathrm{m}}$ of $-50 \mathrm{kPa}$. Nine soil cubes, each 1.2 by 1.2 by $1.0 \mathrm{~cm}$ and weighing $2.0 \mathrm{~g}$ (dry wt), were cut from each soil cake using a household vegetable cutter and placed in 50-ml beakers. Beakers were then capped with squares of cellophane wrap secured with rubber bands and placed in trays. Trays of beakers were sealed in polyethylene bags and incubated in the dark at $20^{\circ} \mathrm{C}$ for 13 days. Excess soil from the cakes was used to determine the percent $\mathrm{H}_{2} \mathrm{O}$ of the soil cubes. Subsamples of slurried soil were used to develop wetting and drying moisture-characteristic curves using Buchner funnel tensiometers and ceramic pressure plates to estimate the soil water $\psi_{\mathrm{m}}$ in soil cubes.

After incubation, $\mathrm{KCl}$ was applied by micropipette to the cubes with $\mathrm{K}$ at 0,150 , 300,450 , or $600 \mu \mathrm{g} / \mathrm{g}$ of soil in $40 \mu \mathrm{l}$ of DW. Beakers were recapped with cellophane wrap and incubated as above for 4 days. Cubes were then flooded by adding $30 \mathrm{ml}$ of DW at $20 \pm 1{ }^{\circ} \mathrm{C}$ to each beaker and baited with $0.5-\mathrm{cm}$-diameter leaf discs punched from the unifoliolate leaves of 17day-old Sloan soybean seedlings. Twenty leaf-disc baits were used per beaker. After $2 \mathrm{~h}$, baits were removed, blotted, and plated on VYS/PBNRH medium. The number of leaf discs infected with $P$. sojae was recorded after 4 days. Excess water was poured out of the beakers and the beakers placed in a drying oven at $110^{\circ} \mathrm{C}$. The dry weight of soil baited was determined after $24 \mathrm{~h}$. Leaf-disc infection was corrected for multiple infections by transforming the proportion of discs infected $(x)$ to $\ln 1 \cdot(1-x)^{-1}$ prior to analysis of variance (45). Treatments were replicated seven times.

Because flooding cubes with DW greatly diluted the $\mathrm{KCl}$ treatments, the bioassay was modified to more closely approximate the $\mathrm{KCl}$ concentrations of saturated soil solutions in growth-chamber experiments. Soil cubes were incubated in the dark for 18 days, then flooded with either soil extract, obtained from saturated soil as described above, or soil extract plus 0.01 or $0.02 \mathrm{M} \mathrm{KCl}$. Treatments were replicated six times. The electrical conductivities of the flooding solutions were measured with the solu bridge. To distinguish the effects of $\mathrm{KCl}$ from the osmotic effects of the flooding solutions, soil extract only was compared with soil extract plus 0.01 $\mathrm{M} \mathrm{NH}_{4} \mathrm{NO}_{3}$.

\section{RESULTS}

More than 260 diseased plants were collected and plated on VYS/PBNRH medium during the above experiments. $P$. sojae was isolated from $95 \%$ of the plated seedlings. Pythium spp. were isolated from

Table 1. Physical and chemical properties of soils used in experiments comparing effects of fertilizer salts on Phytophthora root rot of soybean ${ }^{\vee}$

\begin{tabular}{|c|c|c|c|c|c|c|c|c|c|c|c|c|}
\hline \multirow[b]{2}{*}{ Soil series } & \multicolumn{3}{|c|}{ Particle analysis (\%) } & \multirow[b]{2}{*}{ OM $(\%)^{\mathrm{w}}$} & \multirow[b]{2}{*}{ pH } & \multicolumn{4}{|c|}{ Exchangeable cations $\left(\mathrm{kg} \mathrm{ha}^{-1}\right)$} & \multirow[b]{2}{*}{$\operatorname{CEC}\left(\operatorname{meq} g^{-1}\right)^{x}$} & \multirow[b]{2}{*}{ Base $(\%)^{\mathrm{y}}$} & \multirow[b]{2}{*}{ Elect. $^{\mathrm{z}}$} \\
\hline & Sand & Silt & Clay & & & $\mathbf{P}$ & $\mathbf{K}$ & $\mathrm{Ca}$ & Mg & & & \\
\hline Fulton & 9.0 & 50.3 & 40.7 & 2.7 & $6.7 \mathrm{~b}$ & $74 \mathrm{a}$ & $482 \mathrm{a}$ & $5,465 \mathrm{~b}$ & $1,586 \mathrm{a}$ & $0.20 \mathrm{a}$ & $94 \mathrm{a}$ & 0.39 \\
\hline Hoytville & 16.7 & 42.1 & 41.2 & 5.1 & $6.9 \mathrm{a}$ & $76 a$ & $473 \mathrm{a}$ & $6,928 \mathrm{a}$ & $928 \mathrm{~b}$ & $0.21 \mathrm{a}$ & $95 \mathrm{a}$ & 0.18 \\
\hline Blount & 18.2 & 55.2 & 26.6 & 3.5 & $6.6 \mathrm{~b}$ & $75 \mathrm{a}$ & $306 \mathrm{~b}$ & $4,120 \mathrm{c}$ & $1,004 \mathrm{~b}$ & $0.15 \mathrm{~b}$ & $92 \mathrm{~b}$ & 0.16 \\
\hline
\end{tabular}

v Values in the same column followed by the same letter are not significantly different $(P=0.05)$.

${ }^{\mathrm{w}}$ Organic matter.

${ }^{x}$ Cation exchange capacity.

y Base saturation.

${ }^{\mathrm{z}}$ Electrical conductivity $\left(\mathrm{mmho} \mathrm{cm}^{-1}\right)$. 
$10 \%$, generally in association with $P$. sojae. Representative seedlings with and without necrotic hypocotyls were collected and plated on VYS/PBNRH medium. $P$. sojae was isolated from $80 \%$ of the necrotic hypocotyls; no pathogens were isolated from healthy hypocotyls. No disease developed in cartons with pasteurized soil. With the exception of $\mathrm{KNO}_{2}$ in the initial test, no significant differences in seed germination or seedling emergence with treatment were observed in any experiment. Seedlings usually appeared healthy until 2 to 3 days after soil saturation, when discoloration of the hypocotyls of some seedlings became evident and damping-off began. Post-emergence damping-off increased over the next 2 to 3 days, then gradually abated, except with chloride and ammonium salt treatments. With these treatments, occasional seedlings would develop hypocotyl lesions, wilt, and die throughout the remainder of experiments. At the end of experiments, 8 to $15 \%$ of the surviving plants with $\mathrm{Cl}$ salt treatments had internal hypocotyl necrosis compared with $5 \%$ with other treatments.

Soil analyses. There were significant differences in the nutrient availability among the three collected soils. The Fulton silty clay had more exchangeable $\mathrm{Mg}$ than the other two soils while the Hoytville silty clay had more exchangeable $\mathrm{Ca}$ and the highest $\mathrm{pH}$ (Table 1). The Blount silt loam had the lowest cation exchange capacity and the lowest levels of exchangeable $\mathrm{K}$ and $\mathrm{Ca}$. Incubating naturally infested Fulton silty clay at $25^{\circ} \mathrm{C}$ maximized leaf disc infection with $P$. sojae in the bioassay (Fig. 1). Therefore, this temperature was used as the incubation temperature in subsequent growth-chamber experiments.

Effects of $\mathrm{K}, \mathrm{P}, \mathrm{SO}_{4}, \mathrm{Cl}$, and $\mathrm{NH}_{4}$ salts on disease incidence and plant height. Treatments significantly $(P=0.0228$ to $<0.0001)$ affected disease incidence in all experiments Addition of $\mathrm{KCl}$ at 150 and $200 \mu \mathrm{g}$ of $\mathrm{K}$ per gram of soil increased disease incidence and decreased plant height compared with the untreated control (Table 2). $\mathrm{K}_{2} \mathrm{SO}_{4}$ and $\mathrm{KNO}_{3}$ at similar rates of potassium did not increase disease to levels significantly higher than that observed in the untreated control. Disease incidence with $\mathrm{KNO}_{2}$ was also higher and plants shorter than with the untreated control. $\mathrm{KNO}_{2}$ also significantly reduced seed germination compared with all other treatments $(F$ value $=9.38 ; P=0.001)$. Phosphorus salts at 20 to $40 \mu \mathrm{g}$ of $\mathrm{P}$ had little effect on disease incidence or plant growth. In the experiment with $\mathrm{K}$ salts with $\mathrm{K}$ at $400 \mu \mathrm{g} / \mathrm{g}$ of soil, $\mathrm{KCl}$ again increased disease incidence and decreased plant height compared with the untreated control (Table 3). However, when metalaxyl was applied with the $\mathrm{KCl}$, no Phytophthora rot was observed, and plant height was greater than in all other treatments. Chloride salts of $\mathrm{Na}$ and
$\mathrm{Mg}$ applied at a rate equal to the amount of chloride in the $\mathrm{KCl}$ treatment also increased disease incidence relative to the untreated control. $\mathrm{KHCO}_{3}$ and $\mathrm{CaSO}_{4}(982$ $\mu \mathrm{g}$ of $\left.\mathrm{SO}_{4}\right)$ also increased disease incidence but neither significantly affected plant height compared with the untreated control. Sulfate salts of $\mathrm{Ca}, \mathrm{Na}, \mathrm{Mg}$, and $\mathrm{Al}$ at $491 \mu \mathrm{g}$ of $\mathrm{SO}_{4}$ had no significant effects on disease incidence or plant height.
When six potassium salts with $\mathrm{K}$ at 300 $\mu \mathrm{g} / \mathrm{g}$ of soil were compared with an untreated control, only $\mathrm{KCl}$ increased disease incidence (Table 4). Plant height was lower than the untreated control with $\mathrm{KCl}$, $\mathrm{KNO}_{3}$, and $\mathrm{KH}_{2} \mathrm{PO}_{4}$, with the greatest reduction occurring with $\mathrm{KCl}$. Eight of nine chloride salts with $\mathrm{Cl}$ at $250 \mu \mathrm{g} / \mathrm{g}$ of soil increased disease incidence compared with the untreated control (Table 5). Only

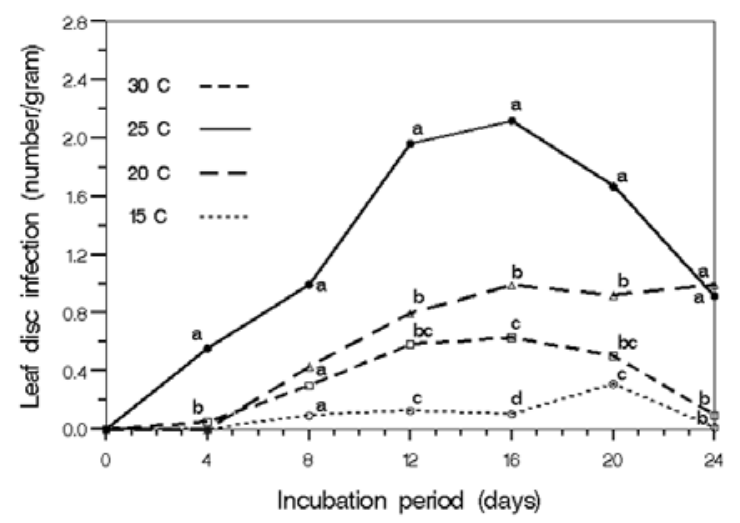

Fig. 1. Number of Amsoy soybean leaf disc baits infected with Phytophthora sojae after incubating naturally infested Fulton silty clay for 4 to 24 days at $15,20,25$, or $30^{\circ} \mathrm{C}$. Values are the means of two replications with five subsamples/replication and 7 to $8 \mathrm{~g}$ of dry soil per subsample. Values for the same day with the same letter are not significantly different $(P=0.05)$.

Table 2. Effects of potassium at 150 or $200 \mu \mathrm{g} / \mathrm{g}$ of soil and phosphorus salts on disease incidence (DI) and height of Sloan soybean plants grown in Fulton silty clay naturally infested with Phytophthora sojae ${ }^{\mathrm{Z}}$

\begin{tabular}{|c|c|c|c|c|c|c|}
\hline \multirow[b]{2}{*}{ Salt } & \multicolumn{4}{|c|}{ Rates ( $\mu \mathrm{g} / \mathrm{g}$ of soil) } & \multirow[b]{2}{*}{ DI (\%) } & \multirow[b]{2}{*}{ Height $(\mathrm{cm}$} \\
\hline & $\mathbf{K}$ & $\mathbf{P}$ & $\mathrm{SO}_{4}$ & Cl & & \\
\hline Control & 0 & 0 & 0 & 0 & $12.5 \mathrm{c}$ & $11.8 \mathrm{a}$ \\
\hline $\mathrm{KCl}$ & 150 & 0 & 0 & 136 & $31.2 \mathrm{a}$ & $9.7 \mathrm{~b}$ \\
\hline $\mathrm{KCl}$ & 200 & 0 & 0 & 181 & $26.5 \mathrm{a}$ & $9.9 \mathrm{~b}$ \\
\hline $\mathrm{K}_{2} \mathrm{SO}_{4}$ & 150 & 0 & 184 & 0 & $20.3 \mathrm{abc}$ & $11.3 \mathrm{a}$ \\
\hline $\mathrm{K}_{2} \mathrm{SO}_{4}$ & 200 & 0 & 246 & 0 & $22.4 \mathrm{abc}$ & $11.3 \mathrm{a}$ \\
\hline $\mathrm{KNO}_{2}$ & 100 & 0 & 0 & 0 & $32.4 \mathrm{a}$ & $9.4 \mathrm{~b}$ \\
\hline $\mathrm{KNO}_{3}$ & 200 & 0 & 0 & 0 & $18.8 \mathrm{abc}$ & $11.3 \mathrm{a}$ \\
\hline $\mathrm{Ca}\left(\mathrm{H}_{2} \mathrm{PO}_{4}\right)_{2}$ & 0 & 20 & 0 & 0 & $12.3 \mathrm{bc}$ & $11.4 \mathrm{a}$ \\
\hline $\mathrm{Ca}\left(\mathrm{H}_{2} \mathrm{PO}_{4}\right)_{2}$ & 0 & 40 & 0 & 0 & $11.0 \mathrm{c}$ & $11.4 \mathrm{a}$ \\
\hline $\mathrm{K}_{2} \mathrm{HPO}_{4}$ & 100 & 40 & 0 & 0 & $14.9 \mathrm{bc}$ & $11.2 \mathrm{a}$ \\
\hline
\end{tabular}

${ }^{\mathrm{z}}$ Values in the same column followed by the same letter are not significantly different $(P=0.05)$.

Table 3. Effects of phosphorus, sulfate, and chloride salts with $\mathrm{K}$ at 0 or $400 \mu \mathrm{g} / \mathrm{g}$ of soil on disease incidence (DI) and height of Sloan soybean plants grown for 18 days in a growth chamber in Fulton silty clay naturally infested with Phytophthora sojae ${ }^{\mathrm{x}}$

\begin{tabular}{|c|c|c|c|c|c|c|}
\hline \multirow[b]{2}{*}{ Salt } & \multicolumn{4}{|c|}{ Rates ( $\mu \mathrm{g} / \mathrm{g}$ of soil) } & \multirow[b]{2}{*}{ DI (\%) } & \multirow[b]{2}{*}{ Height $(\mathrm{cm})$} \\
\hline & $\mathbf{K}$ & $\mathbf{P}$ & $\mathrm{SO}_{4}$ & Cl & & \\
\hline Control & 0 & 0 & 0 & 0 & $13.3 \mathrm{e}$ & $12.5 \mathrm{bc}$ \\
\hline $\mathrm{KCl}$ & 400 & 0 & 0 & 363 & $47.2 \mathrm{ab}$ & $10.2 \mathrm{~d}$ \\
\hline $\mathrm{KCl}+$ metalaxyl $^{\mathrm{y}}$ & 400 & 0 & 0 & 363 & $0.0 \mathrm{f}$ & $15.7 \mathrm{a}$ \\
\hline $\mathrm{K}_{2} \mathrm{SO}_{4}$ & 400 & 0 & 491 & 0 & $21.0 \mathrm{de}$ & $12.7 \mathrm{bc}$ \\
\hline $\mathrm{KH}_{2} \mathrm{PO}_{4}$ & 400 & 317 & 0 & 0 & $14.7 \mathrm{e}$ & $12.2 \mathrm{bc}$ \\
\hline $\mathrm{K}_{2} \mathrm{HPO}_{4}$ & 400 & 159 & 0 & 0 & $17.2 \mathrm{e}$ & $12.3 \mathrm{bc}$ \\
\hline $\mathrm{KHCO}_{3}$ & 400 & 0 & 0 & 0 & $31.3 \mathrm{~cd}$ & $12.5 \mathrm{bc}$ \\
\hline $\mathrm{CaSO}_{4}^{\mathrm{z}}$ & 0 & 0 & 491 & 0 & 24.5 cde & $12.8 \mathrm{~b}$ \\
\hline $\mathrm{CaSO}_{4}{ }^{\mathrm{z}}$ & 0 & 0 & 982 & 0 & $30.9 \mathrm{~cd}$ & $12.3 \mathrm{bc}$ \\
\hline $\mathrm{NaCl}$ & 0 & 0 & 0 & 363 & $36.5 \mathrm{bc}$ & $11.5 \mathrm{c}$ \\
\hline $\mathrm{Na}_{2} \mathrm{SO}_{4}$ & 0 & 0 & 491 & 0 & $21.7 \mathrm{de}$ & $12.2 \mathrm{bc}$ \\
\hline $\mathrm{MgCl}_{2} \cdot 6 \mathrm{H}_{2} \mathrm{O}$ & 0 & 0 & 0 & 363 & $52.4 \mathrm{a}$ & $11.5 \mathrm{c}$ \\
\hline $\mathrm{MgSO}_{4} \cdot 7 \mathrm{H}_{2} \mathrm{O}$ & 0 & 0 & 491 & 0 & 24.5 cde & $12.0 \mathrm{bc}$ \\
\hline $\mathrm{Al}_{2}\left(\mathrm{SO}_{4}\right)_{3} \cdot 18 \mathrm{H}_{2} \mathrm{O}$ & 0 & 0 & 491 & 0 & $21.6 \mathrm{de}$ & $12.8 \mathrm{~b}$ \\
\hline
\end{tabular}

${ }^{\mathrm{x}}$ Values in the same column followed by the same letter are not significantly different $(P=0.05)$.

${ }^{y}$ Soil was drenched with metalaxyl at $5 \mu \mathrm{g}$ a.i. $\mathrm{g}^{-1}$ dry soil.

${ }^{z}$ Dry $\mathrm{CaSO}_{4}$ was mixed with soil as cartons were packed. 
$\mathrm{FeCl}_{3} \cdot 6 \mathrm{H}_{2} \mathrm{O}$ failed to increase disease incidence over the untreated control. The greatest reduction in plant height occurred with this treatment, however. The mean disease incidences with the potassium and chloride salts in these two tests were strongly correlated with the mean electrical conductivity of the soil extracts $(R=$ $0.9153 ; P<0.001)$.

When the effects of $\mathrm{NH}_{4} \mathrm{NO}_{3}$ and $\mathrm{NaCl}$ were tested and compared with the effects of $\mathrm{NaNO}_{3}, \mathrm{NH}_{4} \mathrm{Cl}$, urea, and the control, all salts except $\mathrm{NaNO}_{3}$ increased disease in the saturated-soil experiment (Table 6). In the experiment where the soil was never saturated, $\mathrm{NaNO}_{3}$ also increased disease incidence to a level greater than the untreated control (Table 6). The increase in disease incidence over that in the control with $\mathrm{NH}_{4} \mathrm{Cl}$ was greater than the increase with $\mathrm{NaCl}$ or the increase with $\mathrm{NH}_{4} \mathrm{NO}_{3}$ (Table 6). The reduction in plant height with $\mathrm{NH}_{4} \mathrm{Cl}$ was also greater than with $\mathrm{NaCl}$ or with $\mathrm{NH}_{4} \mathrm{NO}_{3}$ (Table 6). The increase in disease incidence with $\mathrm{NH}_{4} \mathrm{Cl}$ was observed whether or not the soil was saturated to release zoospores (Table 6). Urea, which rapidly hydrolyzes in soils to

Table 4. Effects of six potassium salts on disease incidence (DI) and height of Sloan soybean plants grown for 22 days in a growth chamber in Fulton silty clay naturally infested with Phytophthora sojae and their effects on soil electrical conductivity ${ }^{\mathrm{y}}$

\begin{tabular}{|c|c|c|c|c|c|}
\hline \multirow[b]{2}{*}{ Salt } & \multicolumn{2}{|c|}{ Rates $(\mu \mathrm{g} / \mathrm{g}$ of soil $)$} & \multirow[b]{2}{*}{ DI (\%) } & \multirow[b]{2}{*}{ Height (cm) } & \multirow[b]{2}{*}{ Conductivity $\left(\mathrm{mmho} \mathrm{cm}^{-1}\right)$} \\
\hline & $\mathbf{K}$ & $\mathbf{C l}$ & & & \\
\hline Control & 0 & 0 & $14.4 \mathrm{bc}$ & $12.9 \mathrm{a}$ & $0.93 \mathrm{~d}$ \\
\hline $\mathrm{KCl}$ & 300 & 272 & $35.0 \mathrm{a}$ & $10.6 \mathrm{c}$ & $2.06 \mathrm{a}$ \\
\hline $\mathrm{K}_{2} \mathrm{SO}_{4}$ & 300 & 0 & $25.9 \mathrm{ab}$ & $12.3 \mathrm{ab}$ & $1.52 \mathrm{c}$ \\
\hline $\mathrm{KNO}_{3}$ & 300 & 0 & $26.4 \mathrm{ab}$ & $11.8 \mathrm{~b}$ & $1.75 \mathrm{~b}$ \\
\hline $\mathrm{KHCO}_{3}$ & 300 & 0 & $11.5 \mathrm{c}$ & $12.3 \mathrm{ab}$ & $0.96 \mathrm{~d}$ \\
\hline $\mathrm{K}_{2} \mathrm{HPO}_{4}$ & 300 & 0 & $12.8 \mathrm{c}$ & $12.0 \mathrm{ab}$ & $0.98 \mathrm{~d}$ \\
\hline $\mathrm{KH}_{2} \mathrm{PO}_{4}$ & 300 & 0 & $10.0 \mathrm{c}$ & $11.5 \mathrm{bc}$ & $1.01 \mathrm{~d}$ \\
\hline
\end{tabular}

${ }^{y}$ Values in the same column followed by the same letter are not significantly different $(P=0.05)$.

${ }^{\mathrm{z}}$ Electrical conductivity of water collected from saturated soil after harvesting plants.

Table 5. Effects of nine chloride salts on disease incidence (DI) and height of Sloan soybean plants grown for 22 days in a growth chamber in Fulton silty clay naturally infested with Phytophthora sojae and their effect on soil electrical conductivity ${ }^{y}$

\begin{tabular}{|c|c|c|c|c|c|}
\hline \multirow[b]{2}{*}{ Salt } & \multicolumn{2}{|c|}{ Rates ( $\mu \mathrm{g} / \mathrm{g}$ of soil) } & \multirow[b]{2}{*}{ DI (\%) } & \multirow[b]{2}{*}{ Height (cm) } & \multirow[b]{2}{*}{ 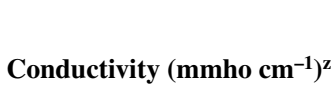 } \\
\hline & $\mathbf{K}$ & Cl & & & \\
\hline Control & 0 & 0 & $13.3 \mathrm{c}$ & $14.8 \mathrm{a}$ & $0.91 \mathrm{e}$ \\
\hline $\mathrm{KCl}$ & 276 & 250 & $28.2 \mathrm{ab}$ & $14.0 \mathrm{ab}$ & $1.96 \mathrm{~cd}$ \\
\hline $\mathrm{NaCl}$ & 0 & 250 & $38.0 \mathrm{a}$ & $13.4 \mathrm{bcd}$ & $2.04 \mathrm{bcd}$ \\
\hline $\mathrm{MgCl}_{2} \cdot 6 \mathrm{H}_{2} \mathrm{O}$ & 0 & 250 & $28.3 \mathrm{ab}$ & $13.7 \mathrm{bcd}$ & $2.12 \mathrm{abc}$ \\
\hline $\mathrm{CaCl}_{2} \cdot 2 \mathrm{H}_{2} \mathrm{O}$ & 0 & 250 & $33.6 \mathrm{ab}$ & $12.9 \mathrm{~cd}$ & $2.21 \mathrm{ab}$ \\
\hline $\mathrm{NH}_{4} \mathrm{Cl}$ & 0 & 250 & $40.4 \mathrm{a}$ & $13.2 \mathrm{bcd}$ & $2.29 \mathrm{a}$ \\
\hline $\mathrm{AlCl}_{3} \cdot 6 \mathrm{H}_{2} \mathrm{O}$ & 0 & 250 & $28.8 \mathrm{ab}$ & $13.3 \mathrm{bcd}$ & $1.88 \mathrm{~d}$ \\
\hline $\mathrm{FeCl}_{2} \cdot 4 \mathrm{H}_{2} \mathrm{O}$ & 0 & 250 & $20.3 b c$ & $12.8 \mathrm{~d}$ & $1.95 \mathrm{~cd}$ \\
\hline $\mathrm{FeCl}_{3} \cdot 6 \mathrm{H}_{2} \mathrm{O}$ & 0 & 250 & $28.3 \mathrm{ab}$ & $13.8 \mathrm{abc}$ & $1.87 \mathrm{~d}$ \\
\hline $\mathrm{SrCl}_{2} \cdot 6 \mathrm{H}_{2} \mathrm{O}$ & 0 & 250 & $32.8 \mathrm{ab}$ & $13.1 \mathrm{bcd}$ & $1.89 \mathrm{~d}$ \\
\hline
\end{tabular}

${ }^{y}$ Values in the same column followed by the same letter are not significantly different $(P=0.05)$.

${ }^{\mathrm{z}}$ Electrical conductivity of water collected from saturated soil after harvesting plants.

Table 6. Effects of chloride and ammonium salts on disease incidence and height of Sloan soybean plants grown in a growth chamber in Fulton silty clay naturally infested with Phytophthora sojae in two experiments, one with and one without soil saturation ${ }^{\mathrm{x}}$

\begin{tabular}{|c|c|c|c|c|c|}
\hline \multirow[b]{2}{*}{ Salt $^{\mathbf{y}}$} & \multicolumn{2}{|c|}{ Rates $(\mu \mathrm{g} / \mathrm{g}$ of soil) } & \multirow[b]{2}{*}{ Height $(\mathbf{c m})$} & \multicolumn{2}{|c|}{ Disease incidence (\%) } \\
\hline & Cl & $\mathbf{N}$ & & Saturated & Not saturated ${ }^{\mathrm{z}}$ \\
\hline Control & 0 & 0 & $14.4 \mathrm{a}$ & $4.3 \mathrm{c}$ & $7.5 \mathrm{c}$ \\
\hline $\mathrm{NH}_{4} \mathrm{NO}_{3}$ & 0 & 120 & $12.1 \mathrm{~cd}$ & $22.3 \mathrm{~b}$ & $24.8 \mathrm{~b}$ \\
\hline $\mathrm{NaCl}$ & 304 & 0 & $11.8 \mathrm{~d}$ & $25.4 \mathrm{~b}$ & $26.0 \mathrm{~b}$ \\
\hline $\mathrm{NaNO}_{3}$ & 0 & 120 & $13.9 \mathrm{ab}$ & $8.4 \mathrm{c}$ & $22.1 \mathrm{~b}$ \\
\hline Urea & 0 & 120 & $11.6 \mathrm{~d}$ & $25.2 \mathrm{~b}$ & $30.3 \mathrm{~b}$ \\
\hline $\mathrm{NH}_{4} \mathrm{Cl}$ & 304 & 120 & $9.3 \mathrm{e}$ & $48.3 \mathrm{a}$ & $55.4 \mathrm{a}$ \\
\hline Urea + pyroxyfur & 0 & 120 & $13.0 \mathrm{bc}$ & $4.3 \mathrm{c}$ & ND \\
\hline
\end{tabular}

${ }^{\mathrm{x}}$ Soybean plants were grown for 20 days with soil saturation and 11 days without soil saturation in separate experiments which were conducted and analyzed separately. Values in the same column followed by the same letter are not significantly different $(P=0.05)$; ND $=$ no data.

${ }^{\mathrm{y}}$ Urea $=$ commercial urea fertilizer $(45-0-0)$ and pyroxyfur $=$ Grandstand seed treatment fungicide (Dowco 444).

${ }^{\mathrm{z}}$ Soil never saturated: plants were grown in sealed polyethylene bags without saturating the soil to release zoospores. ammonium carbonate (44), also increased disease incidence. When seed were treated with pyroxyfur and the soil saturated, the increase in disease incidence with urea was not observed (Table 6). Increases in disease incidence and decreases in plant height relative to the water control occurred when Blount silt loam but not Hoytville silty clay was treated with $\mathrm{KCl}$ at $272 \mu \mathrm{g}$ of $\mathrm{Cl}$ per gram of soil (Table 7). However, disease incidence was increased in both soils when $\mathrm{NH}_{4} \mathrm{Cl}$ at $272 \mu \mathrm{g}$ of $\mathrm{Cl}$ per gram of soil was applied. The salt combination of $\mathrm{KCl}$ at $272 \mu \mathrm{g}$ of $\mathrm{Cl}+$ $\mathrm{Ca}\left(\mathrm{NO}_{3}\right)_{2}$ at $108 \mu \mathrm{g}$ of $\mathrm{N}$ also increased disease incidence in both soils compared with the control (Table 7).

A high rate of $\mathrm{NaCl}(450 \mu \mathrm{g}$ of $\mathrm{Cl})$ did not appreciably affect soybean plants grown in pasteurized Fulton silty clay (Table 8). Seed germination, plant emergence, transpiration, height, and dry weight were essentially unaffected by the added $\mathrm{NaCl}$ compared with the water treatment. Only plant fresh weight was significantly increased by the addition of $\mathrm{NaCl}$. No disease developed in the pasteurized soil.

Effects of $\mathrm{K}$ salts on nutrient levels in soybean seedlings. Application of $\mathrm{KCl}$ but not $\mathrm{K}_{2} \mathrm{SO}_{4}$ decreased the amounts of $\mathrm{S}$ and $\mathrm{Ca}$ and increased the amount of $\mathrm{Cl}$ in taproots relative to the levels found in the untreated control (Table 9). Conversely, $\mathrm{KCl}$ treatment was associated with higher levels of $\mathrm{Ca}$ and lower levels of $\mathrm{Mg}$ in stems and leaves than the control or $\mathrm{K}_{2} \mathrm{SO}_{4}$ treatments. $\mathrm{K}_{2} \mathrm{SO}_{4}$ was associated with less $\mathrm{Ca}$ in stems and leaves than the other two treatments (Table 9). Application of $\mathrm{KCl}$ or $\mathrm{K}_{2} \mathrm{SO}_{4}$ significantly increased the amount of $\mathrm{K}$ in stem and leaves. When soybean plants were grown for 17 days in naturally infested soil treated with $\mathrm{KCl}$ at $300 \mu \mathrm{g}$ of $\mathrm{Cl}$ per gram of soil, EDX analysis indicated that the unifoliolate leaves contained $20 \times$ more $\mathrm{Cl}$ and $2.5 \times$ more $\mathrm{Ca}$ with added $\mathrm{KCl}$ than in the untreated control.

Effect of KCl on inoculum of $P$. sojae. Additions of $\mathrm{KCl}$ to soil cubes 5 days before flooding and baiting with leaf discs apparently had little effect on leaf infection by $P$. sojae $(P>0.65$; data not shown). However, using soil extracts with 0.01 or $0.02 \mathrm{M} \mathrm{KCl}$ to flood the soil cubes apparently adversely affected zoospore infection of leaf discs $(P<0.001)$. The probittransformed value for leaf infection was 0.83 , whereas no leaf infection was observed with extract plus $0.01 \mathrm{M} \mathrm{KCl}$ or extract plus $0.02 \mathrm{M} \mathrm{KCl}$. The electrical conductivities of the solutions were 0.97 , 2.27 , and $3.58 \mathrm{mmho} / \mathrm{cm}$, respectively. When soil extract alone was compared with soil extract plus $0.01 \mathrm{M} \mathrm{NH}_{4} \mathrm{NO}_{3}$, no difference in leaf infection was observed. The electrical conductivities of these solutions were 1.05 and $2.32 \mathrm{mmho} / \mathrm{cm}$, respectively. 


\section{DISCUSSION}

Recently, Elmer (20) summarized the many reports of chloride salts affecting plant diseases. Although the beneficial effects of chloride for disease suppression were well described, the negative effects (disease enhancement) were discussed only briefly. Applications of potassium chloride to the Fulton silty clay consistently increased the incidence of Phytophthora root and stem rot on a susceptible soybean cultivar in the studies reported here. The increases appeared to be related to the rate of $\mathrm{KCl}$ applied, increasing from 27 to 35 to $47 \%$ as the application rate was increased from 200 to 300 to $400 \mu \mathrm{g}$ of $\mathrm{K}$ per gram of soil. In contrast, $\mathrm{K}_{2} \mathrm{SO}_{4}$ did not affect disease incidence at application rates of 150 to $400 \mu \mathrm{g}$ of $\mathrm{K}$. Other potassium salts, most sulfate salts, and phosphorus salts also did not affect disease incidence. The addition of chloride salts, however, consistently increased disease, demonstrating that the increase in disease incidence with applications of $\mathrm{KCl}$ was probably due to the presence of chloride. Previously reported increases in Phytophthora rot with use of a complete fertilizer containing $\mathrm{KCl}$ (15) or with muriate of potash (30) may also have been due, in part, to the presence of chloride. Ammonium salts also increased disease, and these increases were particularly enhanced when combined with chloride with applications of $\mathrm{NH}_{4} \mathrm{Cl}$.

A few exceptions to the overall trends were observed. In the initial test, added $\mathrm{KNO}_{2}$ increased disease incidence and reduced plant height compared with the control. It also reduced seed germination, possibly due to nitrite toxicity. In the tests comparing effects of chloride and ammonium salts (Table 6), $\mathrm{NaNO}_{3}$ increased disease incidence only when the soil was never saturated. This may have been due to a change in denitrification with a change in the partial pressure of oxygen in the sealed polyethylene bags (44) and accumulation of nitrite. The mechanism behind the chloride effect is unclear. The significant decrease in infection in the leaf-disc bioassay when $\mathrm{KCl}$ was added to the flooded soil solution suggests reduced activity of zoospore inoculum. This reduced activity may be due to rapid encystment of zoospores in the presence of $\mathrm{K}$ (7) or decreased release of zoospores (43). Less disease, rather than more, would be expected. Decreases in disease were not observed, possibly due to retention of $\mathrm{K}^{+}$on the negatively charged soil colloids (4).

Disease increases were associated with increases in the electrical conductivity of soil extracts, indicating increases in the osmotic potential of the soil solution (32) and suggesting that salinity stresses may be involved. High salt concentrations have been reported to both increase and decrease the severity of diseases caused by Phytophthora spp. (35). Beech (3) attributed increased damping-off of tomato seedlings with fertilizer salts to a growth advantage of pathogen over host when both were under osmotic stress. This mechanism appears unlikely here because growth of the host was largely unaffected by chloride salt concentrations two to three times greater than those at which significant increases in disease first became evident, whereas growth of Phytophthora spp. is generally reduced by increasing the osmotic potential of media with additions of chloride salts $(40,41)$.

MacDonald (26) reported increased Phytophthora root rot of chrysanthemum with pulsed exposures of roots to salinity stress and suggested that predisposition of roots to zoospore infection as a result of the deplasmolytic shock may have been involved. In our studies, disease was increased with chloride salts when plants were grown in soil at a $\psi_{\mathrm{m}}$ of -5 to -15 $\mathrm{kPa}$ in sealed polyethylene bags without ever saturating the soil. Under these conditions, a deplasmolytic shock was probably not incurred. It seems likely that a mechanism other than deplasmolytic shock must have been involved.

Changes in host physiology with chloride uptake offer an alternative explanation for observed results. Borys (5) noted an increase in the susceptibility of potato leaves to infection by $P$. infestans when plants were grown in sand culture to which chloride salts were added. MacDonald (27) has demonstrated that salinity stresses using chloride salts also appear to increase the susceptibility of host roots to infection by $P$. cryptogea. Details of the mechanism for this effect were largely unknown. In experiments reported here, the calcium content of roots of plants receiving $\mathrm{KCl}$ was lower and the calcium content of stems and leaves higher than those of the water control. However, the calcium content of roots was not affected with $\mathrm{K}_{2} \mathrm{SO}_{4}$. Increases in resistance or tolerance of plant tissues to fungal infection with increases in calcium content have frequently been reported $(1,2,19,25,31)$. Recent reports have also identified the importance of the calcium ion as an important signaling messenger in plant defense mechanisms $(18,24)$. The EDX analyses of intact soybean roots in this report probably reflect the calcium concentration in the outer two or three layers of cells. Movement of calcium out of or through root tissues and into shoots with uptake of chloride could possibly render roots more susceptible to infection. Calcium compounds have recently been reported to reduce the severity of Phytophthora root and stem rot of soybean $(42,43)$. Additional studies are needed to determine whether changes in root calcium

Table 8. Response to sodium chloride of Sloan soybean seedlings grown in pasteurized Fulton silty clay

\begin{tabular}{lcc}
\hline Variable measured $^{\mathbf{y}}$ & No NaCl & With $^{\text {NaCl}}{ }^{\mathbf{z}}$ \\
\hline Seedling emergence 4 DAP (\%) & 97.2 & 97.2 \\
Final germination 9 DAP (\%) & 98.6 & 98.6 \\
Evapotranspiration rate 21 DAP (g/plant/day) & 10.2 & 9.8 \\
Plant height (cm) & 20.3 & 20.2 \\
Plant fresh weight (g) & 1.66 & $1.84^{* *}$ \\
Plant dry weight (g) & 0.214 & 0.216 \\
\hline
\end{tabular}

${ }^{\mathrm{y}} \mathrm{DAP}=$ days after planting.

${ }^{z}$ Added at $450 \mu \mathrm{g} \mathrm{Cl} / \mathrm{g}$ of soil. Value followed by $* *$ differs significantly from the control $(P=$ 0.0065).

Table 7. Effects of $\mathrm{KCl}, \mathrm{K}_{2} \mathrm{SO}_{4}$, and nitrogen salts on disease incidence (DI) and height of Sloan soybean plants grown in a growth chamber for 18 days in Hoytville silty clay or Blount silt loam naturally infested with Phytophthora sojae ${ }^{\mathrm{z}}$

\begin{tabular}{|c|c|c|c|c|c|c|c|}
\hline \multirow[b]{2}{*}{ Salt } & \multicolumn{3}{|c|}{ Rates ( $\mu \mathrm{g} / \mathrm{g}$ of soil) } & \multicolumn{2}{|c|}{ Hoytville silty clay } & \multicolumn{2}{|c|}{ Blount silt loan } \\
\hline & $\mathbf{K}$ & $\mathrm{Cl}$ & $\mathbf{N}$ & DI (\%) & Height (cm) & DI (\%) & Height $(\mathbf{c m})$ \\
\hline Control & 0 & 0 & 0 & $13.0 \mathrm{~b}$ & $13.8 \mathrm{a}$ & $6.9 \mathrm{c}$ & $14.2 \mathrm{a}$ \\
\hline $\mathrm{KCl}$ & 300 & 272 & 0 & $13.7 \mathrm{~b}$ & $12.7 \mathrm{a}$ & $35.1 \mathrm{ab}$ & $11.8 \mathrm{~cd}$ \\
\hline $\mathrm{K}_{2} \mathrm{SO}_{4}$ & 300 & 0 & 0 & $16.2 \mathrm{~b}$ & $13.2 \mathrm{a}$ & $14.4 \mathrm{c}$ & $14.7 \mathrm{a}$ \\
\hline $\mathrm{CO}\left(\mathrm{NH}_{2}\right)_{2}$ & 0 & 0 & 108 & $32.6 \mathrm{ab}$ & $12.5 \mathrm{a}$ & $24.7 \mathrm{bc}$ & $13.3 \mathrm{abc}$ \\
\hline$\left(\mathrm{NH}_{4}\right)_{2} \mathrm{SO}_{4}$ & 0 & 0 & 108 & $21.3 \mathrm{ab}$ & $13.8 \mathrm{a}$ & $21.9 \mathrm{c}$ & $13.7 \mathrm{ab}$ \\
\hline $\mathrm{NH}_{4} \mathrm{Cl}$ & 0 & 272 & 108 & $42.2 \mathrm{a}$ & $13.3 \mathrm{a}$ & $53.9 \mathrm{a}$ & $12.0 \mathrm{bcd}$ \\
\hline $\mathrm{Ca}\left(\mathrm{NO}_{3}\right)_{2}$ & 0 & 0 & 108 & $12.2 \mathrm{~b}$ & $14.8 \mathrm{a}$ & $12.3 \mathrm{c}$ & $13.7 \mathrm{ab}$ \\
\hline $\mathrm{NaNO}_{3}$ & 0 & 0 & 108 & $28.6 \mathrm{ab}$ & $13.7 \mathrm{a}$ & $24.0 \mathrm{bc}$ & $13.8 \mathrm{a}$ \\
\hline $\mathrm{KCl}+\mathrm{Ca}\left(\mathrm{NO}_{3}\right)_{2}$ & 300 & 272 & 108 & $42.6 \mathrm{a}$ & $13.7 \mathrm{a}$ & $54.6 \mathrm{a}$ & $10.3 \mathrm{~d}$ \\
\hline
\end{tabular}

${ }^{\mathrm{z}}$ Values in the same column followed by the same letter are not significantly different $(P=0.05)$. 
Table 9. Elemental analyses of Sloan soybean seedlings grown in pasteurized soil with and without addition of $\mathrm{KCl}$ or $\mathrm{K}_{2} \mathrm{SO}_{4}{ }^{\mathrm{w}}$

\begin{tabular}{|c|c|c|c|c|c|c|c|c|c|c|c|c|}
\hline \multirow[b]{2}{*}{ Treatment $^{\mathrm{z}}$} & \multicolumn{6}{|c|}{ Taproot segments $\left(\text { counts } s^{-1}\right)^{x}$} & \multicolumn{6}{|c|}{ Stems and leaves $(\%)^{\mathrm{y}}$} \\
\hline & Mg & $\mathbf{P}$ & $\mathbf{S}$ & Cl & $\mathbf{K}$ & Ca & Mg & $\mathbf{P}$ & $\mathbf{S}$ & Cl & $\mathbf{K}$ & $\mathbf{C a}$ \\
\hline No salt & $58.3 \mathrm{a}$ & $27.8 \mathrm{a}$ & $85.9 \mathrm{a}$ & $135.8 \mathrm{~b}$ & $237.1 \mathrm{~b}$ & $58.1 \mathrm{a}$ & $0.58 \mathrm{a}$ & $0.52 \mathrm{a}$ & $0.44 \mathrm{~b}$ & NA & $3.62 \mathrm{~b}$ & $0.96 \mathrm{~b}$ \\
\hline $\mathrm{KCl}$ & $37.3 \mathrm{a}$ & $30.8 \mathrm{a}$ & $52.9 \mathrm{~b}$ & $342.6 \mathrm{a}$ & $395.3 \mathrm{ab}$ & $29.9 \mathrm{~b}$ & $0.49 \mathrm{~b}$ & $0.53 \mathrm{a}$ & $0.42 \mathrm{~b}$ & NA & $4.08 \mathrm{a}$ & $1.04 \mathrm{a}$ \\
\hline $\mathrm{K}_{2} \mathrm{SO}_{4}$ & $36.9 \mathrm{a}$ & $19.6 \mathrm{a}$ & $96.6 \mathrm{a}$ & $97.1 \mathrm{~b}$ & $536.4 \mathrm{a}$ & $44.0 \mathrm{ab}$ & $0.55 \mathrm{a}$ & $0.51 \mathrm{a}$ & $0.55 \mathrm{a}$ & NA & $4.26 \mathrm{a}$ & $0.87 \mathrm{c}$ \\
\hline
\end{tabular}

${ }^{\mathrm{w}}$ Values in the same analysis column followed by the same letter are not significantly different $(P=0.05)$; NA $=$ not analyzed.

$\mathrm{x}$ Taproot segments from 5-day-old seedlings by energy-dispersive X-ray analysis.

y Stems and leaves from 10-day-old seedlings using conventional methods for mineral analysis (see text for methods used).

${ }^{\mathrm{z}}$ No salt $=$ control. Potassium salts were added to the soil at $400 \mu \mathrm{g}$ of K per gram of soil.

content associated with chloride uptake might affect the susceptibility of roots to infection or pathogen colonization.

The experiments reported here demonstrate that applications of $\mathrm{KCl}$ can potentially increase the incidence of Phytophthora root and stem rot on soybean seedlings. Additional studies with other soybean cultivars and soils are needed to corroborate these observations. Further exploration of the possible reason for the increase in seedling disease incidence with chloride salts is also needed. Potassium chloride is by far the most widely used potassium fertilizer (44). The possible confounding effects of chloride should be a consideration in any study of the effects of potash fertilizers on seedling diseases.

\section{ACKNOWLEDGMENTS}

Funding for these studies was provided in part by the Ohio Soybean Council. Salaries and research support provided by State and Federal Funds appropriated to the Ohio Agricultural Research and Development Center, The Ohio State University. We thank B. Whitmoyer, OARDC, Department of Plant Pathology, for assistance with energydispersive X-ray analysis of soybean tissues; and J. R. Holman, Computing and Statistical Services, OARDC, and L. V. Madden, OSU Department of Plant Pathology, for advice on statistical analyses.

\section{LITERATURE CITED}

1. Bateman, D. F. 1964. An induced mechanism of tissue resistance to polygalacturonase in Rhizoctonia-infected hypocotyls of bean. Phytopathology 54:438-445.

2. Bateman, D. F., and Lumsden, R. D. 1965. Relation of calcium content and nature of the pectic substances in bean hypocotyls of different ages to susceptibility to an isolate of Rhizoctonia solani. Phytopathology 55:734738 .

3. Beech, W. S. 1949. The effects of excess solutes, temperature and moisture upon dampingoff. Penn. Agric. Exp. Stn. Bull. 509.

4. Bohn, H. L., McNeal, B. L., and O'Connor, G. A. 1979. Soil Chemistry. John Wiley \& Sons, New York.

5. Borys, M. W. 1964. Influence of calcium, magnesium, chloride and sulphate nutrition on the resistance of potato leaves to Phytophthora infestans de Bary. Acta Microbiol. Pol. 13:221226.

6. Butters, B., and Chenery, E. M. 1959. Rapid method for the determination of total sulphur in soils and plants. Analyst 84:239-245.

7. Byrt, P. N., Irving, H. R., and Grant, B. R. 1982. The effect of cations on zoospores of the fungus Phytophthora cinnamomi. J. Gen. Microbiol. 128:1189-1198.

8. Canaday, C. H., and Mengistu, A. 2008. Effects of directed fungicide sprays and potash form on charcoal rot of soybean, 2007. Plant
Disease Management Reports (online) Report 2:FC015. DOI:10.1094/PDMR02.

9. Canaday, C.H., and Mengistu, A. 2009. Effects of potash form, seed treatments, and in-furrow fungicide sprays on soybean diseases, 2008. Plant Disease Management Reports (online) Report 3:FC012. DOI:10.1094/PDMR03.

10. Canaday, C. H., Sams, C. E., Wyatt, J. E., and Schmitthenner, A. F. 1999. Increases in the incidence of seedling diseases associated with chloride salts. (Abstr.) Phytopathology 89:S93.

11. Canaday, C. H., and Schmitthenner, A. F. 1979. The effect of nitrogen on Phytophthora root rot of soybeans. (Abstr.) Phytopathology 69:539.

12. Canaday, C. H., and Schmitthenner, A. F. 1982. Isolating Phytophthora megasperma f. sp. glycinea from soil with a baiting method that minimizes Pythium contamination. Soil Biol. Biochem. 14:67-68.

13. Canaday, C. H., and Schmitthenner, A. F. 1982. Quantification of treatment effects on natural inoculum of Phytophthora megasperma f. sp. glycinea. (Abstr.) Phytopathology 72:996.

14. Canaday, C. H., and Schmitthenner, A. F. 1983. Effect of potassium fertilization and chloride ion on Phytophthora rot of soybeans. (Abstr.) Phytopathology 73:811.

15. Dirks, V. A., Anderson, T. R., and Bolton, E. F. 1980. Effect of fertilizer and drain location on incidence of Phytophthora root rot of soybeans. Can. J. Plant Pathol. 2:179-183.

16. Dorrance, A. E., and McClure, S. A. 2001. Beneficial effects of fungicide seed treatments for soybean cultivars with partial resistance to Phytophthora sojae. Plant Dis. 85:1063-1068.

17. Dorrance, A. E., and Schmitthenner, A. F. 2000. New sources of resistance to Phytophthora sojae in the soybean plant introductions. Plant Dis. 84:1303-1308.

18. Du, L., Ali, G. S., Simons, K. A., Hou, J., Yang, T., Reddy, A. S. N., and Poovaiah, B. W. 2009. $\mathrm{Ca}^{2+} /$ calmodulin regulates salicylic-acidmediated plant immunity. Nature 457:11541158.

19. Edgington, L. V., and Walker, J. C. 1958. Influence of calcium and boron nutrition on development of Fusarium wilt of tomato. Phytopathology 48:324-326.

20. Elmer, W. H. 2007. Chlorine and plant disease. Pages 189-202 in: Mineral Nutrition and Plant Disease. L. E. Datnoff, W. H. Elmer, and D. M. Huber, eds. American Phytopathological Society, St. Paul, MN.

21. Griffin, D. M. 1972. Ecology of Soil Fungi. Syracuse Univ. Press, Syracuse, NY.

22. Hildebrand, A. A. 1959. A root and stalk rot of soybeans caused by Phytophthora megasperma Drechsler var. sojae var. nov. Can. J. Bot. 37:927-957.

23. John, M. K. 1970. Colorimetric determination of phosphorus in soil and plant materials with ascorbic acid. Soil Sci. 109:214-220.

24. Lecourieux, D., Ranjeva, R., and Pugin, A. 2006. Calcium in plant defence-signalling pathoways. New Phytol. 71:249-269.

25. Lee, B. S., and Zentmyer, G. A. 1982. Influ- ence of calcium nitrate and ammonium sulfate on Phytophthora root rot of Persea indica Phytopathology 72:1558-1564.

26. MacDonald, J. D. 1982. Effect of salinity stress on the development of Phytophthora root rot of chrysanthemum. Phytopathology 72: 214-219.

27. MacDonald, J. D. 1984. Salinity effects on the susceptibility of chrysanthemum roots to Phytophthora cryptogea. Phytopathology 74:621624.

28. MacDonald, J. D., and Duniway, J. M. 1978. Influence of the matric and osmotic components of water potential on zoospore discharge in Phytophthora. Phytopathology 68:751-757.

29. Mussell, H. 1980. Tolerance to disease. Pages 39-52 in: Plant Disease, an Advanced Treatise. Vol. V. How Plants Defend Themselves. J. G. Horsfall and E. B. Cowling, eds. Academic Press, New York.

30. Pacumbaba, R. P., Brown, G. F., and Pacumbaba, R. O., Jr. 1997. Effect of fertilizers and rates of application on incidence of soybean diseases in northern Alabama. Plant Dis. 81:1459-1460.

31. Rahman, M., and Punja, Z. K. 2007. Calcium and plant disease. Pages 79-93 in: Mineral Nutrition and Plant Disease. L. E. Datnoff, W. H. Elmer, and D. M. Huber, eds. American Phytopathological Society, St. Paul, MN.

32. Richards, L. A. 1954. Diagnosis and improvement of saline and alkali soils. U. S. Dep. Agric. Agric. Handb. 60.

33. Richards, L. A. 1965. Physical conditions of water in soil. Pages 128-152 in: Methods of Soil Analysis. Part I. Physical and Mineralogical Properties, Including Statistics of Measurement and Sampling. C. A. Black, ed. Am. Soc. Agron., Madison, WI.

34. Schmitthenner, A. F. 1985. Problems and progress in control of Phytophthora root rot of soybean. Plant Dis. 69:362-368.

35. Schmitthenner, A. F., and Canaday, C. H. 1983. Role of chemical factors in development of Phytophthora diseases. Pages 189-196 in: Phytophthora: Its Biology, Taxonomy, Ecology and Pathology. D. C. Erwin, S. BartnickiGarcia, and P. H. Tsao, eds. American Phytopathological Society, St. Paul, MN.

36. Schmitthenner, A. F., and Kroetz, M. E. 1982 Pyroxyfur seed treatment for integrated control of Phytophthora root rot of soybean. (Abstr.) Phytopathology 72:971.

37. Schmitthenner, A. F., and Walker, A. K. 1979. Tolerance versus resistance for control of Phytophthora root rot of soybeans. Pages 35-44 in: Rep. Soybean Seed Res. Conf., 9th Am. Seed Trade Assoc. Publ. 9.

38. Schwinn, F. J. 1983. New developments in chemical control of Phytophthora. Pages 327. 334 in: Phytophthora: Its Biology, Taxonomy Ecology, and Pathology. D. C. Erwin, S. Bartnicki-Garcia, and P. H. Tsao, eds. American Phytopathological Society, St. Paul, MN.

39. Skotland, C. B. 1955. A Phytophthora damping-off disease of soybeans. Plant Dis. Rep. 39:682-683.

40. Sommers, L. E., Harris, R. F., Dalton, F. N., 
and Gardner, W. R. 1970. Water potential relations of three root-infecting Phytophthora species. Phytopathology 60:932-934.

41. Sterne, R. E., Zentmyer, G. A., and Bingham, F. T. 1976. The effect of osmotic potential and specific ions on growth of Phytophthora cinnamomi. Phytopathology 66:1398-1402.

42. Sugimoto, T., Watanabe, K., Yoshida, S., Aino, M., Irie, K., Matoh, T., and Briggs, A. R. 2008.
Select calcium compounds reduce the severity of Phytophthora stem rot of soybean. Plant Dis. 92:1559-1565.

43. Sugimoto, T., Watanabe, K., Yoshida, S., Aino, M., Matsuyama, M., Maekawa, K., and Irie, K. 2007. The effects of inorganic elements on the reduction of Phytophthora stem rot disease of soybean, the growth rate and zoospore release of Phytophthora sojae.
J. Phytopathol. 155:97-107.

44. Tisdale, S. L., and Nelson, W. L. 1975. Soi Fertility and Fertilizers. Macmillan, New York.

45. van der Plank, J. E. 1975. Principles of Plant Infection. Academic Press, New York.

46. Vitosh, M. L., Johnson, J. W., and Mengel, D B. 1995. Tri-state fertilizer recommendations for corn, soybeans, wheat and alfalfa. Ohio State Univ. Ext. Bull. E-2567. 